\title{
Risk of tick-borne infections on the rise
}

$\mathrm{C}$ anadians should be prepared for a big increase in the rates of tick-borne diseases like Lyme disease in the coming years, as milder winters make the country more hospitable for the bugs, according to a New Brunswick biologist.

Vett Lloyd, who studies ticks at Mount Allison University in Sackville, New Brunswick, has seen a six- to eightfold increase in the number of ticks in the province so far this year. And the number of those infected with Lyme disease is inching up; it now stands at around 15\%. "Even if the proportion of infected ticks stays the same, there are so many more of them around that you have a higher chance of encountering them," she says.

The Public Health Agency of Canada says that black-legged ticks, which can transmit Lyme disease to humans, are endemic in parts of many provinces. The agency has seen an increase in the number of cases reported each year. In 2009, the first year that Lyme disease was a nationally reportable disease, there were 128 confirmed cases. By 2011, the latest year for which official statistics are available, that number had more than doubled to 258 .

On Aug. 19, the US Centers for Disease Control and Prevention in Atlanta, Georgia, estimated that the number of people infected with Lyme disease in the US each year was around 300000 , 10 times higher than the number of cases reported to the agency. Lloyd suspects that infection rates are underreported in Canada as well. "We have more stringent criteria here, and our physicians aren't looking for it as much," she says.
The problem is only going to get worse as new species of ticks and disease-causing bacteria find their way north, says Lloyd. In addition to the black-legged ticks, she has evidence that other non-native species are finding a permanent home in Canada, including the lone star tick, one of the most aggressive ticks. And the Borrelia burgdorferi bacterium that causes Lyme disease is not the only strain out there. Lloyd has started to see other disease-causing strains, such as $B$. miyamotoi, which had previously only been found in the US.

"We don't have a clinical assay for that one in humans," she says. "But it is almost certainly making people sick." - Brian Owens, St. Stephen, NB

CMAJ 2013. DOI:10.1503/cmaj.109-4593

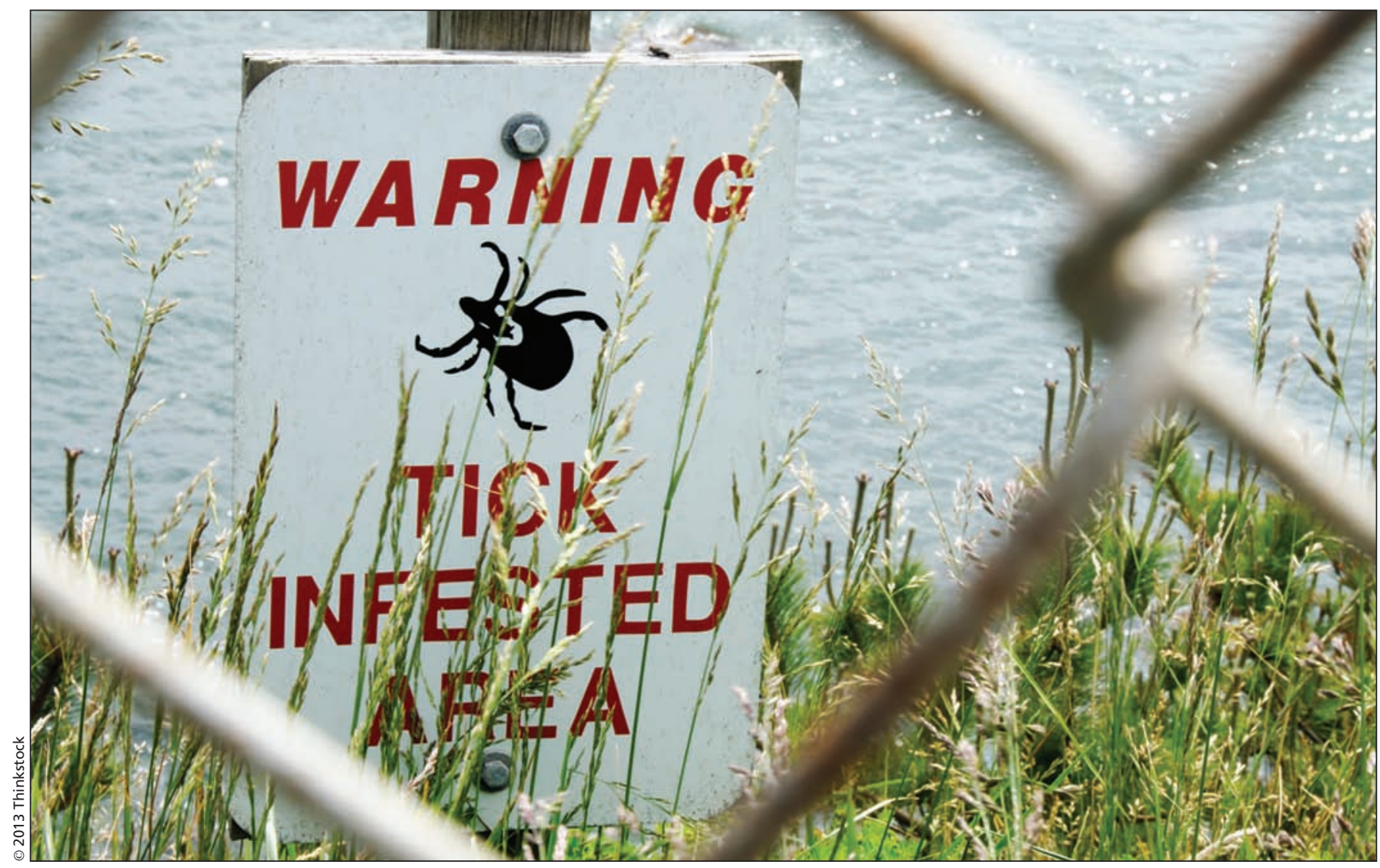

The Public Health Agency of Canada says that black-legged ticks, which can transmit Lyme disease to humans, are endemic in parts of many provinces. 